INSIGHTS INTO REGIONAL DEVELOPMENT

ISSN 2669-0195 (online) http://jssidoi.org/IRD/

2019 Volume 1 Number 1 (March)

http://doi.org/10.9770/IRD.2019.1.1(4)

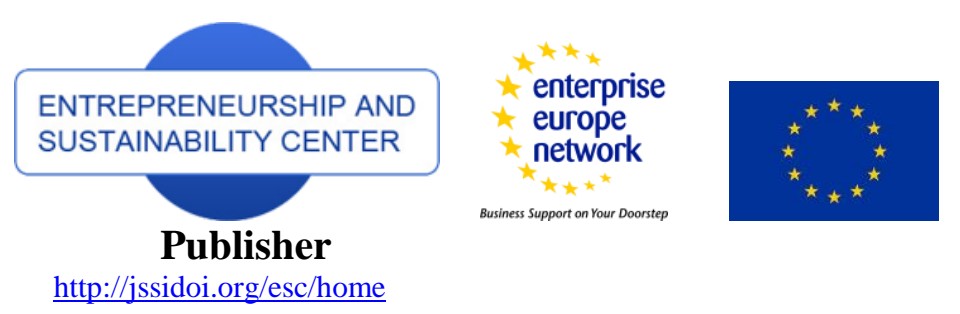

\title{
THE CLASSIFICATION AND COMPARISON OF BUSINESS RATIOS ANALYSIS METHODS*
}

\author{
Sergejs Hilkevics ${ }^{1}$, Valentina Semakina ${ }^{2}$ \\ ${ }^{1.2}$ Ventspils University College, Inženieru iela 101, LV-3601, Ventspils, Latvia \\ E-mails:1hil@venta.lv ; ${ }^{2}$ s5_semaki_v@venta.lv
}

Received 15 November 2018; accepted 20 February 2019; published 30 March 2019

\begin{abstract}
There are many business ratios analysis methods, which are used for different purposes, and the task of these methods classification remains actual business administration problem at present time. In this paper, we suggest two-dimensional classification for business ratios analysis methods. The first dimension is related to the goal of analysis - who and what for performs the business ratios analysis. Usually different real or possible participants of business process perform business ratios analysis for decision-making. There are four main real participants of the business process - owners, workers, managers, society, and two potential participants - creditors and investors. Interests of all participants of the business process are different and therefore the purposes of business ratios analysis can be different. The difference in purposes entails the difference of methods of business ratios analysis, but the common question for all participants of business processes is the question about how their interests are satisfied. The second suggested dimension for business ratios analysis methods classification is the depth of analysis and four levels of analysis are suggested here. The first level is the level of operations and such ratios as earnings (EBITDA, EBIT, EBT, EAT, RE), returns (ROI, ROA, ROE), assets (FA, CA, OF, LTL, CL, TA) are considered at this level. The second level is the financial leverage level and such ratios as Debt/Equity, Interest, Tax, ROE are considered at this level. The third level is the stock market level and such ratios as NPV, EVA, NOPAT, WACC are considered here. The fourth level of business ratios analysis is the functional level or the level of structural units. Independently on the interests of participants of business process, a company should perform such business functions as the creation of organizational structure, financial, human and material resources management, main business activity organization, marketing and others. Usually, special structural units are created in the company to perform most significant business functions, and the quantitative evaluation of business functions performance needs to consider business ratios, which describing appropriate units. Therefore, there are many business ratios analysis methods. The classification and comparison of them give the possibility to take into account, compare the interests of all participants of the business process, and find more qualitative business solutions. Paper considers the classification of business ratios analysis methods and compares them to work out recommendations to balance the interests of different business process participants.
\end{abstract}

Keywords: business ratios; participants of the business process; company efficiency

Reference to this paper should be made as follows: Hilkevics, S.; Semakina, V. 2019. The Classification and Comparison of Business Ratios Analysis Methods, Insights into Regional Development 1(1): 47-56. http://doi.org/10.9770/IRD.2019.1.1(4)

JEL Classifications: G11, M21

\footnotetext{
* The paper was supported by the project "The Development of Innovation and Entrepreneurship in Latvia in Compliance with the Smart Specialization Strategy" within the National Research Program 5.2. "Economic Transformation, Smart Growth, Governance and Legal Framework for the State and Society for Sustainable Development - a New Approach to the Creation of a Sustainable Learning Community (EKOSOC-LV)".
} 


\section{The purposes of business ratios analysis}

There are many business ratios analysis methods, the classification of them is an important part of business administration theory and has a long history. According to Mark Rubinstein book "A history of the theory of investment", valuation methods development stages can be divided into three-time periods - the ancient period (pre-1950), the classical period (1950-1980) and the modern period (post-1980). Interest in evaluation of companies' performance does not fade (e.g. Batkovskiy et al. 2018; Manuylenko et al. 2018; Narkuniené, Ulbinaitè 2018; Zemguliene, Valukonis 2018; Subačienè et al. 2018; Vegera et al. 2018).

In 1949 Benjamin Graham, known as "the father of value investing," expounded his investment philosophy in the popular investment classic, "The Intelligent Investor". Graham's advises based investing on a careful analysis of so called "business fundamentals", paying close attention to price-earnings $(\mathrm{P} / \mathrm{E})$ ratios, dividend yield, and other financial ratios of security analysis. The advice to invest only in stocks with market values not far above the value of their tangible assets laid the foundation for business ratios analysis.

Historically, the first accounting statements-based performance measurement ratios were earnings and returns based only. Since Markowitz (1952) and Roy (1952), financial economists have argued that the second aspect of performance is the risk. The necessity to consider and evaluate risk became a powerful stimulus for business ratios analysis methods development. The first popular method to measure risk from financial statements was the current assets to current liabilities ratio analysis. As the next step, the ratio of earnings before interest and taxes (EBIT) to annual interest payments was suggested as a measure of default risk. Later different authors suggested different default risk measures, until at 1967 Edward Altman using methods of discriminant analysis introduced Z-factor as a valid method for bankruptcy prediction:

$$
\mathrm{Z}=1.2 \mathrm{~A}+1.4 \mathrm{~B}+3.3 \mathrm{C}+0.6 \mathrm{D}+1.0 \mathrm{E},
$$

where A is working capital/total assets, B is retained earnings/total assets, C is earnings before interest and tax/total assets, D is the market value of equity/total liabilities, E is sales/total assets (Kenton, 2018).

In 1964 William F. Sharp developed Capital Asset Pricing Model (CAPM) that divided the expected security return to the sum of the riskless return plus the product of market wide risk aversion and the covariance of security return with the return of the market portfolio. The CAPM can be interpreted as providing a prescription for discounting an uncertain cash flow received at the end of a single period. The CAPM has had a significant influence on subsequent academic work in finance. It is now commonly used by professionals as the backbone of approaches to evaluate investments and measure the performance of investment managers. Moreover, it can be given some credit for encouraging the development of index funds in the decades since its discovery.

In 1999 Stern Stewart \& Company has successfully popularized EVA (economic value added), which became a central ratio for investment decisions making. In 2005 Markus K. Brunnermeier and Jonathan Parker developed the model for the description of relations between behavioral probabilities and preferences. According to this model market participants increase probabilities of outcomes they prefer and decrease probabilities of outcomes they don't like and the analysis of situation needs appropriate business ratios analysis (Rubinstein, 2006). 


\section{INSIGHTS INTO REGIONAL DEVELOPMENT}

ISSN 2669-0195 (online) http://jssidoi.org/jesi/

2019 Volume 1 Number 1 (March)

http://doi.org/10.9770/IRD.2019.1.1(4)

In this paper, we suggest two-dimensional classification for business ratios analysis methods. The first dimension of the suggested classification is related to the goal of analysis - who and what for performs the business ratios analysis. Usually, participants of business process perform business ratios analysis to evaluate how their interests are satisfied in certain business and to work out recommendations for business processes corrections according to their interests. To understand the differences in business ratios analysis methods used by different participants of the business process, it is necessary to consider the interests of real and potential participants of the business process.

There are six main participants of the business process - four real, already existing participants and two potential participants. Real participants are owners, workers, managers, and society, potential participants are creditors and investors.

The main interests of owners of a business are related to business profitability and business market value. Old business administration theory considered the profit as the main interest of owners; modern approaches consider the market value as other significant interest of them. In addition to profitability, the questions related to financial leverage are important to owners. The main business ratios for owners' analysis are ROE, RE, OF, NPV.

The main interests of workers are salary and working conditions, therefore salary and social expenses describing ratios are in the focus of workers' attention in business ratios analysis.

The main interest of society, presented in business processes mostly by state, is the correspondence of business processes to all state laws and regulations, especially to the tax and labor safety regulations. Therefore, tax and labor safety ratios are in the focus of the state's attention.

The main interest of managers is to keep the interests of all real participants in balance and to ensure the longterm existence of a company. Long-term competitiveness of a company depends on many factors, including the ability to generate profit larger than average in the industry during strategic time intervals. The business ratios for analysis from the managerial point of view are earnings (EBITDA, EBIT, EBT, EAT, RE), returns (ROI, ROA, ROE), assets (FA, CA, OF, LTL, CL, TA) and others. The business ratios analysis from the managerial point of view is most complicated comparing with others methods.

The main interest of creditors is to return their credits with maximal interest and minimal risk, therefore the main ratios for analysis are a credit risk, liquidity, debt ratio.

The main interest of investors is the market value of the company, therefore the main ratios for analysis are NPV, EVA, NOPAT, WACC here.

\section{The levels of business ratios analysis}

The second suggested dimension for business ratios analysis methods classification is the depth of analysis and we suggest four levels here.

The first level of business ratios analysis is the level of operations and such ratios as earnings (EBITDA, EBIT, EBT, EAT, RE), returns (ROI, ROA, ROE), assets (FA, CA, OF, LTL, CL, TA) are considered at this level. There are two major operation performance drivers on an operational level - Sales Margin and Sales/Total Assets ratio. Sales Margin measures what is left when the total operating cost is deducted from Sales. Sales to Total Assets ratio identifies the level of the activity of the company. These ratios allow managers to monitor the operational performance of the company. Both Sales Margin and Sales/Total Assets are components of ROTA, which is calculated as EBIT divided by Total Assets (Walsh, 2003, pp. 84-87). 


\section{INSIGHTS INTO REGIONAL DEVELOPMENT}

ISSN 2669-0195 (online) http://jssidoi.org/jesi/

2019 Volume 1 Number 1 (March)

http://doi.org/10.9770/IRD.2019.1.1(4)

The second level of business ratios analysis is the financial leverage level and such ratios as Debt/Equity, Interest, Tax, ROE are considered at this level. The main idea of financial leverage is to use cheap external financial sources instead of expensive internal sources to increase ROE without changing ROA. From the managerial point of view, the most important problem at this level is to ensure the proper balance between profit and risk, because external sources use usually increases both of them. This is the reason why the Debt/Equity ratio has great importance for risk management. The impulse to achieve high returns for the shareholders must be in balance with the risk (Walsh, 2003).

The third level of business ratios analysis is the stock market level and such ratios as NPV, EVA, NOPAT, WACC are considered here. Stock market level includes market to book ratio also, which is calculated dividing ROE by earnings yield (Walsh, 2003). If the growth prospects of a company are good and future promises high returns, the company will be interesting for investors, who are buying the expected future returns. However, they at the same time investors trade off risk against return and for a high-perceived risk, they will look for a high return. Investors weight up many factors - the prospects for the economy overall, industrial sector, particular company (Walsh, 2003) and try to compare the Net Present Value of company with its present market price.

The fourth level of business ratios analysis is the functional level or the level of structural units. Independently on interests of participants of business process, a company should perform such standard business functions as the creation of organizational structure, financial, human and material resources management, main business activity organization, marketing and others. Usually, special structural units are created in the company to perform most significant business functions and the quantitative evaluation of business functions performance needs to consider business ratios, which describe appropriate units.

\section{The classification of business ratios analysis}

The suggested two-dimensional classification of business ratios analysis methods generates the following six by four matrix:

Table 1. The classification of business ratios analysis methods

\begin{tabular}{|c|c|c|c|c|}
\hline & Operations & $\begin{array}{l}\text { Financial } \\
\text { Leverage }\end{array}$ & Market Valuation & Functional Level \\
\hline Owners & $\begin{array}{l}\text { EBITDA, EBIT } \\
\text { EBT, EAT, TA, } \\
\text { FA, CA, OF, } \\
\text { LTL, CL, ROI, } \\
\text { ROA, ROE }\end{array}$ & D/E, ROA, ROE & $\begin{array}{l}\text { NPV, EVA, SVA, } \\
\text { NOPAT, WACC }\end{array}$ & Unit's ratios \\
\hline Workers & Salary & Salary & Salary & Unit's ratios \\
\hline State & Tax & Tax & Tax & Unit's ratios \\
\hline Managers & $\begin{array}{l}\text { EBITDA, EBIT } \\
\text { EBT, EAT, TA, } \\
\text { FA, CA, OF, } \\
\text { LTL, CL, ROI, } \\
\text { ROA, ROE }\end{array}$ & D/E, ROA, ROE & $\begin{array}{l}\text { NPV, EVA, SVA, } \\
\text { NOPAT, WACC }\end{array}$ & Unit's ratios \\
\hline Creditors & $\begin{array}{l}\text { EBITDA, EBIT } \\
\text { EBT, EAT Credit } \\
\text { history }\end{array}$ & $\begin{array}{l}\text { EBITDA, EBIT } \\
\text { EBT, EAT Credit } \\
\text { history }\end{array}$ & $\begin{array}{l}\text { NPV, EVA, SVA, } \\
\text { NOPAT, WACC }\end{array}$ & Unit's ratios \\
\hline
\end{tabular}


INSIGHTS INTO REGIONAL DEVELOPMENT

ISSN 2669-0195 (online) http://jssidoi.org/jesi/

2019 Volume 1 Number 1 (March)

http://doi.org/10.9770/IRD.2019.1.1(4)

\begin{tabular}{|c|c|c|c|c|}
\hline Investors & EBITDA, EBIT & D/E, ROA, ROE & NPV, EVA, SVA, & Unit's ratios \\
& EBT, EAT, OF, & & & \\
& ROI, ROA, ROE & & & \\
\hline
\end{tabular}

Source: made by article's authors

For each cell of Table 1, it is possible to identify business ratios, which are important for the certain participant at the given level. The next question is how to use those ratios for analysis.

Business ratios analysis methods conventionally can be separated into three groups - "hard filtering", "soft filtering" and "indicators calculation". Hard filtering is ratio analysis method when ratios are classified according to diapasons "from-to". For example, if we select stocks for investment, we can take as conditions for selection the following criteria: "Capitalization more than 1 billion" and "ROE from 1\% to 9\%" etc. Soft filtering is ratio analysis method when companies receive rating points for their ratios. Soft filtering is more flexible compared with hard filtering because a company can be selected for investment even if it's capitalization is a little less than one billion, but it has good values of other ratios. Indicators calculation is the method of business ratios analysis which is close to soft filtering, but the calculation of appropriate indicator can be more complicated than rating evaluation and include additional data about the business environment, such as stock market index.

Business ratios analysis methods from the same class can be compared among themselves to identify most appropriate for the user. Let us consider for example several managerial operational level business ratios analysis methods.

\section{Audit-it method}

The audit-it business ratios analysis method is a paid service provided at the international level by audit company "Avdeev \& Co". This system evaluates the company"s ratio, which is called "The Final Rating of Financial Condition" (FRFC) and is a weighted sum of two intermediate ratios - Financial Position and Financial Performance. Financial position ratio includes the following ratios from financial statements - debt ratio, noncurrent assets to net worth, current ratio, quick ratio, and cash ratio. Financial performance includes ROE, ROA and sales growth. Ratios are evaluated from " -2 " (very bad) to " +2 " (excellent) comparing them with the recommended values. Estimation criteria are described in Table 2.

Table 2 Audit-it method estimation criteria

\begin{tabular}{|c|c|}
\hline Ratio & Criteria \\
\hline Debt ratio & $" 2 "<0.15 \leq " 1 " . \leq 0.3<" 0 " \leq 0.5<"-1 "<0.6 \leq "-2 "$ \\
\hline $\begin{array}{l}\text { Non-current assets to net } \\
\text { worth }\end{array}$ & $" 2 "<0.5 \leq " 1 " \leq 1<" 0 " \leq 1.25<"-1 " \leq 2<"-2 "$ \\
\hline Current ratio & "-2" $<1 \leq$ “ $-1 "<2 \leq " 0 "<2.1 \leq " 1 "<2.5<" 2 "$ \\
\hline Quick ratio & " $-2 "<0.5 \leq$ " $-1 "<1 \leq$ " $0 "<1.1 \leq$ " $1 "<1.5<" 2 "$ \\
\hline Cash ratio & "-2" < $0.05 \leq$ “-1" $<0.2 \leq$ "0" $<0.22<" 1 "<0.25 \leq$ "2" \\
\hline ROE & " $-2 "<0 \leq "-1 "<0.06 \leq " 0 "<0.12<" 1 "<0.2 \leq " 2 "$ \\
\hline ROA & " $-2 "<0 \leq$ " 1 " $<0.03 \leq " 0 "<0.06<" 1 "<0.1 \leq$ "2" \\
\hline Sales growth & "-2"<-0.3<“-1" <- $0.04<$ “0" < $0.04<"+1$ " <0.3<"+2" \\
\hline
\end{tabular}

Source: (Audit-it, 2018) 
In audit-it method ratios estimations are calculated for different time periods - past, present, and future. Value for the past is calculated as the arithmetical average of the calculated ratios before the reporting period. Value for the present is equal to ratio value for the reporting period. Value for the future is calculated as linear trend extrapolation for 1 year ahead from the reporting period.

Each of time period (past, present, future) has its own "time weight factor"- $25 \%$ for past, $60 \%$ for present and $15 \%$ for future (Audit-it, 2018). In addition to "time weight factor, each ratio has its own "significance weight factor" listed in Table 3.

Table 3 Significance weight factors for Audit-it factors

\begin{tabular}{|c|c|c|}
\hline Ratio & Ratio Group & 0.3 \\
\hline Debt ratio & Financial position & 0.15 \\
\hline $\begin{array}{c}\text { Non-current assets to net } \\
\text { worth }\end{array}$ & Financial position & 0.2 \\
\hline Current ratio & Financial position & 0.2 \\
\hline Quick ratio & Financial position & 0.15 \\
\hline Cash ratio & Financial position & 0.5 \\
\hline ROE & Financial performance & 0.3 \\
\hline ROA & Financial performance & 0.2 \\
\hline
\end{tabular}

Source: (Ready ratios, 2018)

The Final Rating of Financial Condition (FRFC) is calculated by the following formula (Audit-it, 2018):

FRFC $=$ Financial $_{\text {position }}{ }^{\times} 0.6+$ Financial performance $^{\times} 0.4$

\section{Lursoft method}

Lursoft business ratios analysis is method is a service provided by Latvian company Lursoft. The Lursoft rating of the company is calculated using six major ratios:

1. Solvency- characterizes the specific weight of the company equity capital in the total assets. The specific weight of this index in the determination of rating is $30 \%$.

2. Profit before taxes - shows profit or loss of the company for the period before withholding of taxes. The specific weight in rating determination is $20 \%$

3. Liquidity - characterizes the ability of the company to settle its short-term liabilities. The specific weight of this index in rating determination is $20 \%$.

4. Turnover increase - average increase for the last three years. If the company is younger, the last available years are considered. The specific weight in rating determination is $10 \%$.

5. Return on equity - net profit divided by the equity capital. The specific weight in rating determination is $10 \%$.

6. Liabilities - creditor turnover for the last accounting year. The specific weight in rating determination is $10 \%$.

According to each index (solvency, liquidity, etc.), the companies are ranked from the largest to the smallest. They are each assigned a rating point from 0 to 100. The company ranked first gets 100 rating points, the middle 
rank gets 50 rating points, while the last gets 0 points. Other companies get the points proportionally in accordance with their rank (LURSOFT, 2018).

\section{Corporate success evaluation method}

Corporate success evaluation method was developed by the group of authors (Barhatov, 2016) for the evaluation of success degree of Russian companies. According to this methodology, the main company`s success evaluation criteria are the ability to grow, ability to make profit and ability to achieve outlined objectives. Methodology offers three business ratios based indicators and one time factor related indicator for assessing the success of the company. The first success indicator is sales revenue growth rate $\left(\mathrm{BS}_{1}\right), \mathrm{BS}_{1}=\frac{\mathrm{TR}-\mathrm{TR}^{-1}}{\mathrm{TR}^{-1}}$ where $\mathrm{TR}-$ sales revenue in the current year, $\mathrm{TR}^{-1}-$ sales revenue in the previous year. The second success indicator is the return on sales $\left(\mathrm{BS}_{2}\right), \mathrm{BS}_{2}=\frac{\mathrm{E}}{\mathrm{S}}$ where $\mathrm{E}-$ net profit for the period of review, $\mathrm{S}-$ sales revenue for the period of review. The third success indicator is return on assets $\left(\mathrm{BS}_{3}\right), \mathrm{BS}_{3}=\frac{\mathrm{E}}{\mathrm{A}}$ where $\mathrm{E}-$ net profit for the period of review, $\mathrm{A}-$ total assets at the end of the period of review. To consider the time factor, methodology suggests using the indicator $R_{4}^{\mathrm{t}}$ with a minimum value of 0 and maximum value 1 :

$\mathrm{R}_{4}^{\mathrm{t}}=\frac{N}{N_{\text {max }}}=\frac{\mathrm{t}-\mathrm{T}_{\text {found }}}{\mathrm{t}-1991}$ where $\mathrm{t}$ is current year, $\mathrm{N}$ - company`s existence in a number of years

$\mathrm{N}_{\max }$ - company`s maximum possible existence in a number of years (counting since 1991)

$\mathrm{T}_{\text {found }}$ - company`s foundation (registration) year.

The overall score of the company`s success in points is determined by the sum of all indicators.

\section{Comparison of business ratios analysis methods}

For the situation analysis in different Baltic countries and for the business ratios analysis methods comparison we have calculated ratings of Baltic stocks companies according to all above mentioned methods. Data for Latvian companies are presented in Table 4, data for Baltic companies are analyzed in the other article presented at this conference. For Latvian stock companies, results are as follows.

Table 4. The comparison of business ratios analysis methods

\begin{tabular}{|c|c|c|c|c|c|c|c|c|c|c|c|}
\hline Company & $\begin{array}{l}\text { Final } \\
\text { score }\end{array}$ & $\begin{array}{c}\text { Financial } \\
\text { position }\end{array}$ & $\begin{array}{c}\text { Financial } \\
\text { performance }\end{array}$ & $\begin{array}{c}\text { sales } \\
\text { growth }\end{array}$ & $\begin{array}{l}\text { NI to } \\
\text { sales }\end{array}$ & $\begin{array}{l}\text { NI to } \\
\text { TA }\end{array}$ & $\begin{array}{c}\text { Lurso } \\
\mathbf{f t}\end{array}$ & $\begin{array}{l}\text { Price } \\
2016\end{array}$ & $\begin{array}{l}\text { Price } \\
2017\end{array}$ & $\begin{array}{c}\text { Price } \\
\text { change }\end{array}$ & $\begin{array}{c}\text { Price } \\
\text { change } \\
\%\end{array}$ \\
\hline Brīvais Vilnis & 0.05 & -1.05 & 1.70 & -0.12 & -0.05 & -0.05 & 1.90 & 0.94 & 0.80 & -0.14 & -0.15 \\
\hline $\begin{array}{c}\text { Ditton } \\
\text { pievadķēžu } \\
\text { rūpnīca }\end{array}$ & -0.59 & -1.95 & 1.45 & -0.05 & -0.33 & -0.30 & 3.10 & 0.08 & 0.19 & 0.11 & 1.34 \\
\hline Grindeks & 1.35 & 1.10 & 1.73 & -0.01 & 0.02 & 0.02 & 3.70 & 4.39 & 6.80 & 2.41 & 0.55 \\
\hline Grobina & -1.16 & -1.74 & -0.30 & 0.08 & -0.24 & -0.02 & 2.20 & 2.50 & 6.00 & 3.50 & 1.40 \\
\hline
\end{tabular}


INSIGHTS INTO REGIONAL DEVELOPMENT

ISSN 2669-0195 (online) http://jssidoi.org/jesi/

2019 Volume 1 Number 1 (March)

http://doi.org/10.9770/IRD.2019.1.1(4)

\begin{tabular}{|c|c|c|c|c|c|c|c|c|c|c|c|}
\hline Hansa Matrix & -0.23 & -1.58 & 1.80 & 0.15 & -0.04 & -0.03 & 3.20 & 7.95 & 8.14 & 0.19 & 0.02 \\
\hline $\begin{array}{c}\text { Kurzemes } \\
\text { atslega }\end{array}$ & 1.15 & 0.79 & 1.70 & -0.02 & -0.02 & -0.02 & 3.50 & 1.15 & 1.53 & 0.38 & 0.33 \\
\hline $\begin{array}{l}\text { Latvijas } \\
\text { Balzams }\end{array}$ & 1.00 & 0.61 & 1.60 & 0.03 & 0.10 & 0.06 & 4.00 & 7.52 & 8.20 & 0.68 & 0.09 \\
\hline Latvijas Gāze & 1.31 & 1.13 & 1.57 & 0.02 & 0.08 & 0.05 & 3.60 & 8.78 & 10.00 & 1.22 & 0.14 \\
\hline $\begin{array}{l}\text { Latvijas Jūras } \\
\text { medicīnas } \\
\text { centrs }\end{array}$ & 1.37 & 1.10 & 1.77 & 0.07 & 0.07 & 0.04 & 3.90 & 2.50 & 8.00 & 5.50 & 2.20 \\
\hline Olainfarm & 1.02 & 0.50 & 1.80 & 0.14 & 0.12 & 0.10 & 3.20 & 8.51 & 8.05 & -0.46 & -0.05 \\
\hline PATA Saldus & -0.24 & -1.60 & 1.80 & 0.09 & 0.01 & 0.02 & 3.40 & 17.00 & 18.50 & 1.50 & 0.09 \\
\hline $\begin{array}{c}\text { Rīgas } \\
\text { autoelektroap } \\
\text { arātu rūpnīca }\end{array}$ & -0.60 & -0.42 & -0.87 & -0.31 & -7.05 & -0.05 & 1.20 & 0.23 & 0.19 & -0.04 & -0.17 \\
\hline $\begin{array}{c}\text { Rīgas } \\
\text { elektromašīnb } \\
\text { ūves rūpnīca }\end{array}$ & 0.27 & -0.81 & 1.90 & 0.07 & 0.01 & 0.01 & 3.30 & 1.26 & 2.87 & 1.61 & 1.28 \\
\hline $\begin{array}{c}\text { Rīgas } \\
\text { juvelierizstrā } \\
\text { dājumu } \\
\text { rūpnīca }\end{array}$ & 1.39 & 1.21 & 1.66 & 0.02 & -0.12 & -0.05 & 3.00 & 0.12 & 0.09 & -0.03 & -0.23 \\
\hline $\begin{array}{c}\text { Rīgas kuǵu } \\
\text { būvētava }\end{array}$ & 0.01 & -0.77 & 1.19 & -0.31 & -0.03 & -0.01 & 2.00 & 0.36 & 0.26 & -0.09 & -0.26 \\
\hline SAF Tehnika & 1.50 & 1.31 & 1.78 & 0.04 & 0.06 & 0.06 & 2.90 & 3.51 & 6.45 & 2.94 & 0.84 \\
\hline $\begin{array}{c}\text { Siguldas } \\
\text { ciltslietu un } \\
\text { mākslīgās } \\
\text { apsēklošanas } \\
\text { stacija } \\
\end{array}$ & 1.48 & 1.40 & 1.60 & 0.02 & 0.10 & 0.07 & 3.40 & 3.00 & 3.60 & 0.60 & 0.20 \\
\hline $\begin{array}{c}\text { Valmieras } \\
\text { stikla škiiedra }\end{array}$ & -0.41 & -1.76 & 1.62 & 0.12 & 0.06 & 0.05 & 2.90 & 3.11 & 3.70 & 0.59 & 0.19 \\
\hline VEF & 0.36 & -0.51 & 1.68 & 0.04 & 0.09 & 0.02 & 3.30 & 0.43 & 1.50 & 1.07 & 2.49 \\
\hline $\begin{array}{c}\text { VEF } \\
\text { Radiotehnika } \\
\text { RRR }\end{array}$ & 0.08 & -0.51 & 0.96 & -0.13 & -0.10 & 0.09 & 3.50 & 0.11 & 0.18 & 0.07 & 0.63 \\
\hline $\begin{array}{l}\text { Price growth } \\
\text { correlation }\end{array}$ & -0.04 & $\mathbf{- 0 . 0 7}$ & 0.05 & 0.28 & 0.20 & -0.11 & 0.30 & & & & \\
\hline
\end{tabular}

Source: made by article's authors

There are two main sequences from Table 4 data and one of them was expected before the research and other was not expected. The expected sequence is that different operational level managerial business ratios analysis methods give very similar results. It means, that after ordering by one or another method's rating we receive very similar lists, where only several stock companies are changed in order, the correlation between indicators of different systems and even between components of indicators are very high. For example, for Latvian stock companies correl (final_score, financial_position) $=0.94$, correl (busn_success, financial_performance) $=0.77$, correl (busn_success, Lursoft_rating) $=0.65$, correl (net_incom_to_sales, Lursoft_rating) $=0.63$, correl (sales_growth, Lursoft_rating) $=0.6$.

By other words, as it was expected we receive independent direct confirmation of the high degree of accordance between different managerial business ratios analysis methods. It is natural, that on the operational level problem, which is identified by one method would be identified by other methods also. 


\section{INSIGHTS INTO REGIONAL DEVELOPMENT}

ISSN 2669-0195 (online) http://jssidoi.org/jesi/

2019 Volume 1 Number 1 (March)

http://doi.org/10.9770/IRD.2019.1.1(4)

The result which was unexpected is that for Latvian stock companies there are no direct relations between the results of company managerial operational level evaluation and stock price growth as a reflection of market evaluation. For example, correl (final_score, price_change $\%)=-0.04$, correl (Lursoft_rating, price_change $\%$ ) $=$ 0.3 , correl (busn_success, price_change $\%$ ) $=0.2$. It means, that prices of stocks for companies with good Audit-it ratings can be not growing, but prices of stocks for companies with bad Audit-it ratings can be growing. In less degree, but the same situation is with Lursoft and business success ratings - operational level business ratios are not directly related to stock price growth.

The theoretical explanation of this unexpected experimental observation for Latvian stock companies is that market is sensitive not only to operational level processes but for financial leverage level processes also. If the company can attract financial resources with interest rate significantly less than profit, ROE can be considerably higher than ROA, which is very attractive for investorsand promotes the stock price growth, but such effects are not visible on the operational level. Therefore, the operational level managerial business ratios analysis methods can not be efficiently used for investment decisions making and other methods should be used instead.

\section{Conclusions}

1. In this paper, we suggest two-dimensional classification for business ratios analysis methods.

2. We have considered several operational level managerial business ratios analysis methods and used them for Latvian stock companies ratings calculation.

3. As it was expected, we have received independent direct confirmation of the high degree of accordance between different managerial business ratios analysis methods.

4. As it was unexpected, we have received experimental confirmation that managerial level business analysis methods can not be directly used for investment decisions making.

\section{References}

Audit-it. (2019). Reiting finansovogo sostojanija. Retrieved from Audit-it: https://www.audit-it.ru/finanaliz/manual/\#_metodika_index.php

Barhatov V.I., P. D. (2016). Model uspeshnogo predprijatija malogo i srednego biznesa v Rossiji: monografija. Moskva: Published by Pero

Batkovskiy, A.M.; Efimova, N.S.; Kalachanov, V.D.; Semenova, E.G.; Fomina, A.V.; Balashov, V.M. (2018). Evaluation of the efficiency of industrial management in high-technology industries. 2018. Entrepreneurship and Sustainability Issues 6(2): 577-590.

$\underline{\text { http://doi.org/10.9770/jesi.2018.6.2(8) }}$

Kenton, W. (2018). Altman Z-Score. Retrieved from Investopedia: https://www.investopedia.com/terms/a/altman.asp

LURSOFT (2018). Rating of the company. Retrieved from LURSOFT: https://www.lursoft.lv/en/rating-of-the-company

Manuylenko, V.V.: Loktionova, M.A.; Lipchiu, N.V.; Sobchenko, N. V., Sadovskaya, T.A. (2018). Options simulation toolkit for strategic evaluation of corporations' financial potential, Entrepreneurship and Sustainability Issues 6(2): 871-889. http://doi.org/10.9770/jesi.2018.6.2(27)

Narkunienè, J.; Ulbinaitè, A. (2018). Comparative analysis of company performance evaluation methods, Entrepreneurship and Sustainability Issues 6(1): 125-138. http://doi.org/10.9770/jesi.2018.6.1(10)

Ready ratios (2018). Calculation of the Final Rating of the Financial Condition. Retrieved from Ready Ratios: https://www.readyratios.com/features/full_report.html 
INSIGHTS INTO REGIONAL DEVELOPMENT

ISSN 2669-0195 (online) http://jssidoi.org/jesi/

2019 Volume 1 Number 1 (March)

http://doi.org/10.9770/IRD.2019.1.1(4)

Rubinstein, M. (2006). A history of the theory of investment. Hoboken: Published by John Wiley \& Sons, Inc.

Subačienè, R.; Alver, L.: Brūna, I.; Hladika, M.; Mokošová, D.; Molín, J. 2018. Evaluation of accounting regulation evolution in selected countries, Entrepreneurship and Sustainability Issues 6(1): 139-175. http://doi.org/10.9770/jesi.2018.6.1(11)

Vegera, S.; Malei, A.; Trubovich, R. 2018. Accounting development of natural resources in organizations carrying out the disposal of municipal waste and biogas extraction in the context of the "green" economy, Entrepreneurship and Sustainability Issues 6(1): 211-225. http://doi.org/10.9770/jesi.2018.6.1(14)

Walsh, C. (2003). Key management ratios. Harlow: Published by Prentice Hall Financial Times.

Zemguliene, J.; Valukonis, M. (2018). Structured literature review on business process performance analysis and evaluation, Entrepreneurship and Sustainability Issues 6(1): 226-252. http://doi.org/10.9770/jesi.2018.6.1(15)

\section{Ackowledgements}

The paper was supported by the project "The Development of Innovation and Entrepreneurship in Latvia in Compliance with the Smart Specialization Strategy" within the National Research Program 5.2. "Economic Transformation, Smart Growth, Governance and Legal Framework for the State and Society for Sustainable Development - a New Approach to the Creation of a Sustainable Learning Community (EKOSOC-LV)".

Short biographical note about the contributors at the end of the article (name, surname, academic title and scientific degree, duties, research interests):

Sergejs HILKEVICS is the Professor of Faculty of Economics and Business Administration of Ventspils University College, Latvia. He is member of Scientific Committee of several conferences, his work has attracted best research paper award in the USA. Research interests: fundamental and technical analysis; investment theory and applications; business ratios analysis.

ORCID ID: orcid.org/0000-0003-3555-1729

Valentina SEMAKINA is the researcher in the project "The development of the methodology for companies' busieness ratios analysis" at the Faculty of Economics and Business Administration of Ventspils University College. Research interests: fundamental and technical analysis; investment theory and applications; business ratios analysis.

ORCID ID: orcid.org/0000-0001-9556-8069

Copyright (C) 2019 by author(s) and VsI Entrepreneurship and Sustainability Center

This work is licensed under the Creative Commons Attribution International License (CC BY).

http://creativecommons.org/licenses/by/4.0/

cC) (†) Open Access 